\title{
PENGARUH PROFITABILITAS TERHADAP HARGA SAHAM DENGAN KEBIJAKAN DIVIDEN DAN LEVERAGE SEBAGAI VARIABEL PEMODERASI PADA PERUSAHAAN SEKTOR INDUSTRI BARANG KONSUMSI YANG TERDAFTAR DI BURSA EFEK INDONESIA
}

\author{
Jovial Budi Ramadhani ${ }^{1}$, Lalu Hamdani $\mathbf{H}^{2}$, I Nyoman Nugraha AP3
}

${ }^{1}$ Master of Management Program, Universitas Mataram. E-mail: heyjov77@gmail.com 2,3Faculty of Economics and Business, Mataram University, Indonesia

\begin{tabular}{|c|c|}
\hline ARTICLE INFO & ABSTRACT \\
\hline Keywords : & This study aims to analyze the effect of \\
\hline & profitability on stock prices with dividend and leverage \\
\hline Profitability, Stock Prices, Dividend & policies as moderating variables in the consumer goods \\
\hline Policy, Leverage & $\begin{array}{l}\text { industry sector companies listed on the Indonesia Stock } \\
\text { Exchange (IDX). The independent variable used is }\end{array}$ \\
\hline How to cite: & $\begin{array}{l}\text { Profitability (ROA), with dividend policy (DPR) and } \\
\text { leverage (DER) as moderating variables. The dependent }\end{array}$ \\
\hline Ramadhani, Jovial Budi., Husnan, Lalu & variable is the stock price.The sampling technique was \\
\hline Hamdani., $\quad A P, \quad I \quad$ Nyoman & purposive sampling in order to obtain a total sample of 8 \\
\hline Nugraha. (2020). Pengaruh & companies, with the study period during 2010-2016. The \\
\hline Profitabilitas Terhadap Harga Saham & type of research is associative causal. The data analysis \\
\hline Dengan Kebijakan Dividen dan & technique in this study is moderated regression analysis \\
\hline Leverage Sebagai Variabel Pemoderasi & (MRA) using SPSS. The results of this study indicate that \\
\hline Pada Perusahaan Sektor Industri & profitability has no effect on stock prices. Dividend policy \\
\hline Barang Konsumsi Yang Terdaftar & is proven to be able to strengthen the influence of \\
\hline $\begin{array}{l}\text { Di Bursa Efek Indonesia. JMM } \\
\text { UNRAM, 9(1), 42-52 }\end{array}$ & $\begin{array}{l}\text { profitability on stock prices. And leverage is proven to not } \\
\text { be able to moderate the effect of profitability on stock } \\
\text { prices. }\end{array}$ \\
\hline $\begin{array}{l}\text { DOI : } \\
\text { http://dx.doi.org/10.29303/jmm.v9i }\end{array}$ & $\begin{array}{l}\text { Penelitian ini bertujuan untuk menganalisis } \\
\text { pengaruh profitabilitas terhadap harga saham dengan }\end{array}$ \\
\hline 1.483 & $\begin{array}{l}\text { kebijakan dividendan leverage sebagai variabel moderasi } \\
\text { pada perusahaan sektor industri barang konsumsi yang }\end{array}$ \\
\hline : 28 Agustus 2019 & terdaftar di Bursa Efek Indonesia (BEI). Variabel \\
\hline : 04 September 2019 & independen yang digunakan adalah Profitabilitas (ROA), \\
\hline :05 September 2019 & $\begin{array}{l}\text { dengan kebijakan dividen (DPR) dan leverage (DER) } \\
\text { sebagai variabel moderasi. Variabel dependen adalah harga } \\
\text { saham. Teknik pengambilan sampel adalah purposive } \\
\text { sampling sehingga diperoleh jumlah sampel sebanyak } 8 \\
\text { perusahaan, dengan periode penelitian selama 2010-2016. } \\
\text { Jenis penelitian ini adalah asosiatif kausal. Teknik analisis } \\
\text { data dalam penelitian ini adalah moderated regression } \\
\text { analysis (MRA) menggunakan SPSS.Hasil dari penelitian } \\
\text { ini menunjukkan bahwa profitabilitas tidak berpengaruh }\end{array}$ \\
\hline
\end{tabular}




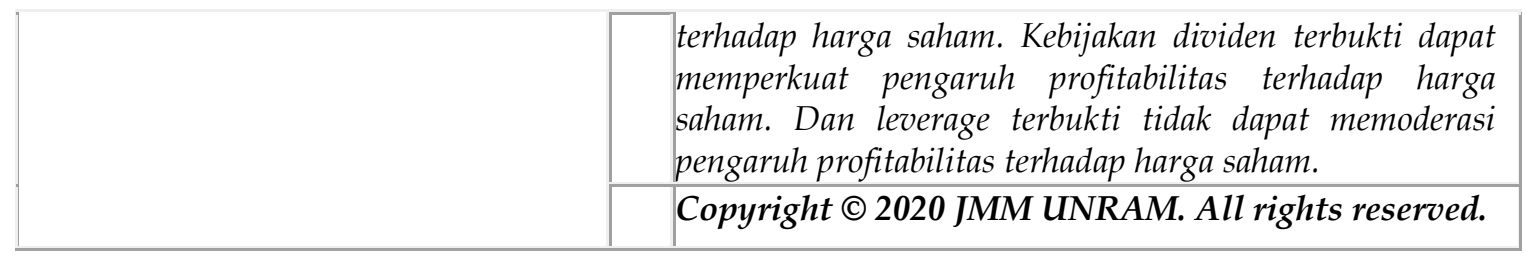

\section{PENDAHULUAN}

Dalam dunia keuangan sangat penting untuk menilai kondisi fundamental, prospek dan prediksi harga saham perusahaan dalam jangka panjang, Alat analisis yang sering digunakan adalah rasio keuangan. Menurut Kasmir (2009:127), jenis rasio keuangan terdiri dari, Rasio likuiditas, Ratio Solvabilitas (leverage ratio), Ratio Aktivitas dan Ratio Profitabilitas. Dalam penelitian ini digunakan profitabilitas diproksikan dengan return on assets (ROA), kebijakan dividen diproksikan dengan dividend payout ratio (DPR) dan leverage diproksikan dengan debt to equity ratio (DER). Variabel-variabel ini dipilih karena sangat penting untuk mengetahui kinerja keuangan suatu perusahaan dan dapat mempengaruhi harga saham, Rasio-rasio ini bisa dijadikan bahan pertimbangan untuk investor agar menjadi tolok ukur para investor dalam memutuskan apakah akan berinvestasi ataupun tidak pada perusahaan sektor industry barang konsumsi yang terdaftar di Bursa Efek Indonesia (BEI).

Menurut Brigham and Houston (2011:148), ROA adalah rasio profitabilitas yang mengukur seberapa besar perusahaan dapat meningkatkan laba bersih perusahaan dengan menggunakan seluruh aset yang dimiliki perusahaan.Semakin tinggi ROA yang dikelola oleh perusahaan maka profitabilitas yang dicapai suatu perusahaan semakin bagus. Meningkatnya laba bersih perusahaan maka perusahaan memiliki kinerja yang baik dan memiliki prospek yang bagus untuk kedepannya. Semakin tinggi profitabilitas perusahaan maka akan meningkatkan kepercayaan investor terhadap perusahaan. Tingginya tingkat kepercayaan investor akan berpengaruh terhadap respon publik tentang perusahaan yang akhirnya juga akan mempengaruhi permintaan saham sehingga tinggi rendahnya rasio ini berpengaruh terhadap harga saham (Djazuli, 2006:54).

Dalam penelitian ini kebijakan dividen yang di proksikan dengan Dividend Payout Ratio (DPR) digunakan sebagai variabel pemoderasi karena Besarnya Return On Assets (ROA) tidak memberikan kepastian bahwa harga saham akan meningkat karena terdapat suatu kondisi kebijakan dividen, kondisi ini dikaitkan dengan penentuan apakah laba yang diperoleh perusahaan akan dibagikan kepada para pemegang saham sebagai dividen atau akan ditahan dalam bentuk laba ditahan. Artinya pengumuman pembayaran dividen sebagai pertanda bagi perkiraan manajemen atas laba, ada kecenderungan harga saham akan naik jika ada pengumuman kenaikan dividen.

Alasan Leverage yang diproksikan dengan Debt to Equity Ratio (DER) digunakan sebagai variabel moderasi karena perusahaan-perusahaan dengan profit yang tinggi cenderung menggunakan lebih banyak pinjaman untuk memperoleh manfaat dalam aspek pajak, hal ini dikarenakan adanya penghematan pajak yang didapatkan perusahaan dengan penggunaan hutang. Selain itu, biaya penerbitan saham lebih mahal daripada penerbitan surat hutang dalam struktur modal perusahaan, penggunaan hutang akan menempatkan perusahaan dan manajer dalam pengawasan pihak eksternal. (Ananda: 2016). Sesuai dengan teori trade off teory, bunga yang dibayarkan sebagai beban pengurang pajak membuat utang lebih murah daripada saham biasa atau preferen (Brigham \& Houston,2011). 
Hasil temuan penelitian terdahulu menunjukkan adanya perbedaan dari faktorfaktor yang mempengaruhi harga saham. Penelitian yang dilakukan Mahadewi (2014) Hasil penelitian menemukan bahwa ROAsecara parsial berpengaruh positif dan signifikan terhadap harga saham, sedangkan penelitian Natasya (2017) menemukan ROA tidak berpengaruh terhadap harga saham. Setyawan (2015) dan Ayu (2017) dalam penelitiannyamenemukan bahwa profitabilitas yang dimoderasi oleh kebijakan dividen berpengaruh signifikan terhadap nilai perusahaan. Anggraini (2017) menemukan bahwa Debt To Equity Ratio (DER) mampu memoderasi hubungan profitabilitas terhadap nilai perusahaan.

Rata-rata faktor yang mempengaruhi harga saham menunjukkan hasil yang masih fluktuatif, hal ini kemudian menjadi fenomena gap. Dalam data yang diperoleh menunjukkan bukti bahwa setiap peningkatan dan penurunan dari Profitabilitas, Kebijakan Dividend dan Leverage tidak diikuti dengan peningkatan dan penurunan harga saham.

Tabel 1.1. rata-rata harga saham, return on asset, dividend payout ratio dan debt to equity ratio pada perusahaan Sektor Industri Barang Konsumsi tahun 2010-2016 :

\begin{tabular}{|c|c|c|c|c|c|}
\hline \multirow{2}{*}{ NO } & TAHUN & $\begin{array}{c}\text { Rata-rata } \\
\text { Harga Saham }\end{array}$ & $\begin{array}{c}\text { Rata-rata } \\
\text { ROA }\end{array}$ & $\begin{array}{c}\text { Rata-rata } \\
\text { DPR }\end{array}$ & $\begin{array}{c}\text { Rata-rata } \\
\text { DER }\end{array}$ \\
\hline 1 & 2010 & 19.633 & 9.44 & 20.18 & 2.64 \\
\hline 2 & 2011 & 19.208 & 8.77 & 16.31 & 1.16 \\
\hline 3 & 2012 & 6.767 & 9.12 & 20.25 & 1.13 \\
\hline 4 & 2013 & 20.600 & 10,08 & 22,80 & 2,67 \\
\hline 5 & 2014 & 21.046 & 7,75 & 14,49 & 0,08 \\
\hline 6 & 2015 & 8.281 & 7,69 & 24,10 & 1,14 \\
\hline 7 & 2016 & 5.714 & 7,37 & 26,63 & 0,85 \\
\hline \multicolumn{5}{|c|}{ Sumber: Data di olah, 2019} \\
\multicolumn{5}{|l}{}
\end{tabular}

\section{TINJAUAN PUSTAKA}

\subsection{Harga Saham}

Menurut Jogiyanto (2008), "Harga saham adalah harga yang terjadi di pasar bursa pada saat tertentu yang ditentukan oleh pelaku pasar dan ditentukan oleh permintaan dan penawaran saham yang bersangkutan di pasar modal". Sedangkan menurut Suad Husnan dan Enny Pudjiastuti (2004), harga saham merupakan nilai sekarang (present value) dari penghasilan-penghasilan yang akan diterima oleh pemodal dimasa yang akan datang.

\subsection{Profitabilitas}

Menurut Sutrisno (2012:16) "profitabilitas adalah kemampuan perusahaan dalam menghasilkan keuntungan dengan semua modal yang bekerja didalamnya".

\subsection{Kebijakan Dividen}

Hal yang paling penting dari kebijakan dividen adalah apakah memungkinkan untuk mempengaruhi kekayaan pemegang saham dengan mengubah rasio pembayaran dividen, yaitu kebijakan dividen (Weston dan Copeland, 1996:105).Menurut Brigham \& Houston, (2001), bahwa terdapat empat teori dari preferensi investor mengenai kebijakan dividen, Yaitu : Pertama Dividend Irrelevance Theory, kebijakan dividen perusahaan tidak mempunyai pengaruh baik terhadap nilai perusahaan maupun biaya modalnya.Kedua Bird In The Hand Theory, Myron Gordon dan John Lintner berpendapat kebijakan dividen berpengaruh positif terhadap nilai perusahaan. Artinya, jika dividen yang dibagikan perusahaan semakin besar, harga pasar saham perusahaan tersebut akan semakin tinggi dan sebaliknya. Ketiga Teori Preferensi Pajak, investor mungkin lebih menyukai pembagian deviden yang rendah daripada yang tinggi. Keempat Information Content, or 
Signalling Hypothesis, Miller dan Modigliani berpendapat bahwa perubahan harga saham sesudah pembagian dividen hanya menunjukkan ada kandungan informasi atau pengisyaratan (information, or signalling content).

\subsection{Leverage}

Rasio leverage mengukur sejauh mana perusahaan menggunakan pendanaan melalui utang. Selama tingkat hutang lebih tinggi menaikkan laba per saham yang diharapkan, leverage bekerja mengungkit harga saham, namun tingkat hutang yang lebih tinggi juga meningkatkan risiko perusahaan yang menaikkan ekuitas dan selanjutnya menurunkan harga saham (Brigham \& Houston, 2001)

\section{METODE PENELITIAN}

Jenis Penelitian ini adalah asosiatif-kausal (sebab-akibat). Penelitian ini bertujuan untuk mengetahui hubungan sebab akibat antara variabel independen yaitu Profitabilitas diproksikan dengan Return On Asset (ROA), terhadap Variabel dependen yaitu harga saham, dan kebijakan dividen diproksikan dengan Dividend Payout Ratio (DPR), leverage diproksikan dengan Debt To Equity Ratio (DER) sebagai variabel moderasi.

Populasi dalam penelitian ini adalah semua perusahaan sektor industri barang konsumsi (Consumer Goods Industry) yang terdaftar di Bursa Efek Indonesia periode tahun 2010-2016 sebanyak 51 perusahaan. Jumlah sampel adalah 8 perusahaan. Jenis data dalam penelitian ini adalah kuantitatif dan sumber data adalah data sekunder. Data penelitian diambil dari annual report dan laporan keuangan yang diperoleh antara lan dari Bursa Efek Indonesia (www.idx.co.id).Analisis data pada penelitian ini menggunakan softwareSPSSyang meliputi: analisis statistic, analisis regresi linier, moderate regresion analisys (MRA).

\section{HASIL PENELITIAN DAN PEMBAHASAN}

\subsection{Analisis Statistik}

1) Uji Normalitas

Tabel 4.1. Hasil Uji Kolmogorov Smirnov (KS)

\begin{tabular}{|c|c|}
\hline Variabel & Sign \\
\hline Harga Saham & 0.805 \\
\hline ROA & 0.445 \\
\hline DPR & 0.075 \\
\hline DER & 0.754 \\
\hline
\end{tabular}

Sumber : Data di olah, 2019

Hasil di atas menunjukkan bahwa variabel harga saham, Return On Asset, Dividend Payout Ratio dan Debt to Equity Ratio memenuhi asumsi normal. Hal ini disebabkan nilai dari Sign yang > Alpha 5\% (Sign > 0.05).

2) Uji Heteroskedastisitas 


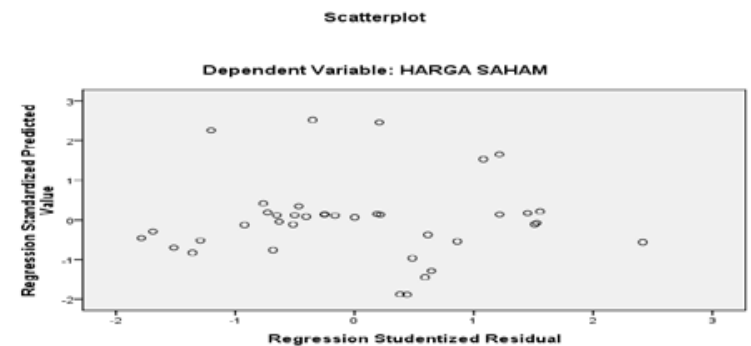

Sumber : Data di olah, 2019

Hasil Gambar 4.1. diatas menunjukkan bahwa titik-titik menyebar dan tidak ditemukan pola tertentu maka mengindikasikan tidak terjadi heteroskedastisitas pada model regresi ROA, DPR dan DER.

3) Uji Multikolinearitas

Tabel 4.2. Hasil Uji Multikolinearitas

\begin{tabular}{|c|c|}
\hline Model & VIF hitung \\
\hline ROA & 1.025 \\
\hline DPR & 1.023 \\
\hline DER & 1.007 \\
\hline
\end{tabular}

Sumber : Data di olah, 2019

Hasil analisis diatas menunjukkan nilai VIF yang terjadi semuanya di bawah 10. Hal ini menunjukkan bahwa semua variable yang diuji memenuhi asumsi bebas multikolinier. Artinya tidak terjadi saling hubungan/korelasi antar variable bebas $(\mathrm{X})$.

\section{4) Uji Autokorelasi}

Uji autokorelasi bertujuan menguji apakah terjadi korelasi diantara data pengamatan.Untuk mengetahui adanya autokorelasi dalam model regresi penelitian ini digunakan uji Durbin-Watson Test dengan hasil :

Tabel 4.3. Hasil Uji Durbin-Watson

\begin{tabular}{|c|c|c|}
\hline No & Nilai DW & Kesimpulan \\
\hline 1. & $1.65<1.818<2.35$ & Tidak ada Autokorelasi \\
\hline
\end{tabular}

Sumber : Data di olah, 2019

Berdasarkan hasil analisis tersebut nilai DW hitung 1.818, maka nilai tersebut terletak diantara nilai 1.65 dan 2.35 yang berada pada kesimpulan tidak terjadi autokorelasi pada data variable terikat. Dengan kata lain, berdasarkan analisis Durbin Watson, hasilnya menunjukkan bahwa seluruh data di Harga Saham (variable $Y$, terikat) adalah saling bebas.

\subsection{Analisis Persamaan Regresi}

1) Perbandingan koefisien determinasi $\left(R^{2}\right)$ efek utama dan efek moderasi.

Tabel 4.4. Hasil Perbandingan Efek Utama dan Efek Moderasi

\begin{tabular}{|c|c|c|}
\hline No & Efek Utama $\left(\boldsymbol{R}^{\mathbf{2}}\right)$ & Efek Moderasi $\left(\boldsymbol{R}^{\mathbf{2}}\right)$ \\
\hline 1. & 0.067 & 0.155 \\
\hline
\end{tabular}

Sumber : Data di olah, 2019

Berdasarkan tabel diatas nilai koefisien determinasi $\left(R^{2}\right)$ efek utama sebesar 0.067 dan nilai koefisien determinasi $\left(R^{2}\right)$ efek moderasi sebesar 0.155 . karena nilai $\left(R^{2}\right)$ efek moderasi lebih besar dibandingkan dengan $\left(R^{2}\right)$ efek utama maka angka ini menunjukkan bahwa Dividend Payout Ratio dan Debt To Equity Ratio bisa digunakan sebagai variable pemoderasi.

2) Uji t 
Pengujian ini dilakukan untuk mengetahui signifikansi pengaruh variabel bebas secara parameter individual (parsial) terhadap variabel terikat, guna menjawab hipotesis 1 Profitabilitas berpengaruh terhadap harga saham, hipotesis 2 Kebijakan dividen dapat memoderasi pengaruh profitabilitas terhadap harga saham, hipotesis 3 Leverage dapat memoderasi pengaruh Profitabilitas terhadap harga saham.

Tabel 4.5. Hasil Uji t Profotabilitas Terhadap Harga Saham

\begin{tabular}{|c|c|c|c|}
\hline Model & B & $\mathrm{t}$ & Sign \\
\hline (Constant) & 3.639 & 9.938 & .000 \\
\hline ROA & .315 & 1.006 & .321 \\
\hline
\end{tabular}

Sumber : Data di olah, 2019

Dengan melihat tabel 4.5. tersebut maka dapat disusun persamaan regresi linear sebagai berikut :

$$
\mathrm{Y}=3,639+0,315 X_{1}
$$

Dari persamaan di atas maka dapat diartikan sebagai berikut :

1. Makna konstanta sebesar 3,639

Jika variabel Independen Profitabilitas bernilai 0, maka nilai variabel dependen harga saham sebesar 3,639 persen.

2. Makna Koefisien regresi variabel $X_{1}$ sebesar 0,315

Angka koefisien regresi sebesar 0,315 tersebut mempunyai arti bahwa bila profitabilitas naik sebesar 1 persen, maka harga saham akan naik sebesar 0,315 persen dengan asumsi variabel lain adalah konstan.

Tabel 4.6. Hasil Uji t Regresi Linear Moderasi

\begin{tabular}{|c|c|c|c|}
\hline Model & $\mathrm{B}$ & $\mathrm{t}$ & Sign \\
\hline (Constant) & 20.917 & 3.204 & .003 \\
\hline ROA & -11.868 & -2.584 & .014 \\
\hline DPR & -10.230 & -2.623 & .013 \\
\hline DER & -.169 & -.119 & .906 \\
\hline ROA*DPR & 7.228 & 2.652 & .012 \\
\hline ROA*DER & .395 & .345 & .732 \\
\hline
\end{tabular}

Sumber : Data di olah, 2019

Dengan melihat tabel 4.6. tersebut maka dapat disusun persamaan regresi linear sebagai berikut :

$$
\mathrm{Y}=20,917-11,87 X_{1}-10,23 X_{2}-0,17 X_{3}+7,23 X_{1}{ }^{*} Z_{1}+0.395 X_{1}{ }^{*} Z_{2}
$$

Dari persamaan di atas maka dapat diartikan sebagai berikut :

1. Makna konstanta sebesar 20,917

Jika variabel Independen Profitabilitas, interaksi (ROA*DPR) dan interaksi (ROA*DER) bernilai 0, maka nilai variabel dependen harga saham sebesar 20,917 persen.

2. Makna koefisien regresi variabel $X_{1}{ }^{*} Z_{1}$ sebesar 7,228

Bila variabel interaksi (ROA*DPR) naik sebesar 1 persen, maka harga saham akan naik sebesar 7,228 persen dengan asumsi variabel lain adalah konstan.

3. Makna koefisien regresi variabel $X_{1}{ }^{*} Z_{2}$ sebesar 0.395

Bila variabel interaksi (ROA*DER) naik sebesar 1 persen, maka harga saham akan naik sebesar 0,395 persen dengan asumsi variabel lain adalah konstan.

Selain menjelaskan persamaan regresi linear, Tabel 4.5 dan 4.6. juga akan menjawab hipotesis penelitian karena mampu menginterpretasikan arah hubungan dan tingkat signifikansi. Dimana berdasarkan hasil uji t pada tabel 4.5 menunjukkan bahwa profitabilitas berpengaruh positif dan tidak signifikan terhadap harga saham, kesimpulan ini didapatkan dari nilai $t$ hitung yang lebih kecil dari $t$ tabel, dimana $t$ 
hitung untuk variable profitabilitas (Return On Assets) sebesar 1,006 dengan nilai Sign $>$ Alpha 5\% (0.321 >0.05). dan pada tabel 4.6 interaksi profitabilitas dengan kebijakan dividen memiliki pengaruh positif dan signifikan terhadap harga saham, kesimpulan ini didapatkan dari nilai $t$ hitung yang lebih besar dari $t$ tabel, dimana $t$ hitung untuk interaksi profitabilitas (Return On Assets) dengan Kebijakan dividen (Dividend Payout Ratio) sebesar 2.652 dengan nilai Sign < Alpha 5\% $(0.012<0.05)$. kemudian interaksi variabel profitabilitas (Return On Assets)dengan Variabel Leverage (Debt To Equity Ratio) memiliki Pengaruh Positif dan tidak signifikan terhadap harga saham, dimana t hitungnya sebesar 0.345 lebih kecil dari t tabel dengan Sign > Alpha 5\% (0.732>0.05).

3) Klasifikasi Variabel Moderasi

Tabel 4.7. Hasil Klasifikasi Variabel Moderasi

\begin{tabular}{|c|l|l|l|}
\hline No & \multicolumn{1}{|c|}{$\begin{array}{l}\text { Variabel } \\
\text { Moderasi }\end{array}$} & \multicolumn{1}{|c|}{ Hasil Uji } & Jenis Moderasi \\
\hline 1 & $\begin{array}{l}\text { Kebijakan } \\
\text { Dividen (DPR) }\end{array}$ & $\begin{array}{l}\text { Efek Utama = significant } \\
\text { Efek Moderasi = significant }\end{array}$ & QuasiModerasi \\
\hline 3 & Leverage (DER) & $\begin{array}{l}\text { Efek Utama = nonsignificant } \\
\text { Efek Moderasi = nonsignificant }\end{array}$ & Homologiser Moderasi \\
\hline
\end{tabular}

Sumber: Data di olah, 2019

Berdasarkan Tabel 4.7. diatas Kebijakan Dividen (Dividend Payout Ratio) merupakan variabel moderasi semu (Quasi Moderasi), dimana Kebijakan Dividen memoderasi hubungan variabel bebas profitabilitas dan variabel terikat harga saham, dimana variabel moderator semu berinteraksi dengan variabel bebas dengan sekaligus menjadi variabel bebas. Sedangkan Leverage (Debt To Equity Ratio) merupakan variabel moderasi potensial (Homologiser Moderasi), dimana Leverage menjadi variabel moderasi yang mempengaruhi kekuatan hubungan antara variabel bebas profitabilitas dan variabel terikat harga saham. Dimana variabel ini tidak berinteraksi dengan variabel bebas dan tidak mempunyai hubungan yang signifikan dengan variabel terikat.

\subsection{Pembahasan Hasil Penelitian}

Hasil penelitian akan dijelaskan dan diinterpretasikan dalam hubungannya dengan hipotesis atau pernyataan atas jawaban sementara yang telah disusun. Pembahasan hasil penelitian merupakan pemikiran yang dilakukan dengan cara mengaitkan antara hasil penelitian atau temuan penelitian dengan teori-teori serta hasil penelitian terdahulu yang digunakan.

\section{1) Pengaruh Profitabilitas terhadap Harga Saham.}

Hipotesis dalam penelitian ini yaitu diduga Profitabilitas berpengaruh positif dan signifikan terhadap harga saham. Hasil analisis data menyatakan bahwa profitabilitas mempunyai pengaruh Positif dan tidak signifikan terhadap harga saham. Artinya, dapat disimpulkan bahwa hipotesis pertama terbukti menolak $\mathrm{H}_{1}$.

Profitabilitas memiliki koefisien positif dan tidak signifikan, ini berarti Profitabilitas tidak berpengaruh terhadap harga saham, artinya setiap kenaikan atau penurunan profitabilitas tidak berpengaruh terhadap perubahan harga saham. Berdasarkan data harga saham tahun 2010hingga tahun 2016 pelemahan profitabilitas tidak berpengaruh terhadap penurunan harga saham perusahaan sektor industri barang konsumsi, bahkan ketika profitabilitas melemah justru harga saham terus meningkat tiap tahunnya. 
Dalam hal ini peneliti beranggapan Investor tidak hanya melihat profitabilitas perusahaan dalam jangka pendek tetapi juga profitabilitas perusahaan dalam jangka panjang, misalnya dengan melihat nilai EVA (Economic Value Added), dimana investor dapat mengestimasi keuntungan ekonomis perusahaan selama periode tertentu dan EVA secara substansial berbeda dengan laba akuntansi, hal ini disebabkan oleh adanya elemen biaya modal yang diperhitungkan dalam EVA yang tidak diperhitungkan dalam laba akuntansi tradisional.

Selain itu investor lebih memperhatikan dari segi kebijakan dividen yang dikeluarkan perusahaan, dengan manajemen perusahaan mengeluarkan kebijakan dividen misalnya maka akan menjadi sebuah signal positif yang memungkinkan para investor tertarik untuk membeli saham perusahaan sektor industri barang konsumsi, sehingga tingginya permintaan terhadap saham akan diikuti peningkatan harga saham.

Hasil analisis data dalam penelitian ini sejalan dengan penelitian yang dilakukan oleh Natasya (2017) yang menyatakan bahwa profitabilitas tidakberpengaruh terhadap harga saham.

2) Pengaruh Profitabilitas terhadap Harga Saham dengan Kebijakan dividen Sebagai Variabel Pemoderasi.

Hipotesis dalam penelitian ini adalah semakin tinggi kebijakan dividen akan memperkuat pengaruh profitabilitas terhadap harga saham. Analisis data dalam penelitian ini menyatakan bahwa kebijakan dividen yang dikeluarkan perusahaan memperkuat pengaruh profitabilitas terhadap harga saham. Artinya, dapat disimpulkan bahwa hipotesis kedua terbukti menerima $\mathrm{H}_{2}$.

Hasil penelitian menunjukkan model moderasian yang digunakan tepat untuk membuat hubungan antar variabel, dalam hal ini kebijakan dividen mampu memoderasi pengaruh profitabilitas terhadap harga saham. Perusahaan dengan Profitabilitas yang tinggi belum tentu akan memiliki harga saham yang tinggi juga, hal tersebut akan menjadi berbeda jika perusahaan dalam kondisi mengeluarkan kebijakan dividen.

Kebijakan dividen merupakan sebuah sinyal baik (good news) bagi investor dalam mengambil keputusan investasi. Dalam teori information content or signaling hypothesis menyatakan bahwa kenaikan dividen merupakan suatu sinyal kepada investor bahwa manajemen meramalkan suatu penghasilan yang baik dimasa yang akan datang. Hal ini sejalan dengan Myron Gordon dan John Lintner dalam Bird In The Hand Theoryberpendapat kebijakan dividen berpengaruhpositifterhadap nilai perusahaan. Artinya, jika dividen yang dibagikan perusahaan semakin besar, hargasaham perusahaan tersebut akan semakin tinggi.

Hasil analisis data dalam penelitian ini sejalan dengan penelitian yang dilakukan oleh Setyawan (2015) dan Ayu (2017) yang menyatakan bahwa kebijakan dividen akan memperkuat pengaruh profitabilitas terhadap harga saham.

\section{3) Pengaruh Profitabilitas terhadap Harga Saham dengan Leverage Sebagai \\ Variabel Pemoderasi.}

Hipotesis dalam penelitian ini adalah semakin tinggi leverage akan memperkuat pengaruh profitabilitas terhadap harga saham. Hasil analisis data menyatakan bahwa leverage tidak dapat memoderasi pengaruh profitabilitas terhadap harga saham. Artinya dapat disimpulkan bahwa hipotesis ketiga terbukti menolak $\mathrm{H}_{3}$.

Menurut trade-off teory yang diungkapkan oleh Myers (2001), "Perusahaan akan berhutang sampai pada tingkat hutang tertentu, dimana penghematan pajakdari 
tambahan hutang sama dengan biaya kesulitan keuangan". Biaya kesulitan keuangan adalah biaya kebangkrutan dan biaya keagenanyang meningkat akibat dariturunnya kredibilitas suatu perusahaan.

Artinya, struktur modal yang optimal berada pada keseimbangan antara manfaat pajak atas penggunaan hutang dengan biaya yang berhubungan dengan kebangkrutan, pada tingkat hutang yang optimal diharapkan nilai perusahaan akan mencapai nilai optimal, dan sebaliknya apabila terjadi tingkat perubahan hutang sampai melewati tingkat optimal atau biaya kebangkrutan, hutang akan mempunyai efek negatif terhadap nilai perusahaan.

Semakin tinggi tingkat hutang suatu perusahaan, akan semakin tinggi juga kemungkinan kebangkrutannya sehingga adanya penilaian negative dari para investor atau pemegang saham menyebabkan mereka tidak tertarik untuk berinvestasi pada perusahaan sector industry barang konsumsi, yang pada akhirnya akan berpengaruh terhadap pergerakan harga saham yang cenderung menurun. Hal ini sejalan dengan pernyataan Brealey, Myers dan Marcus (2006) yang menyimpulkan dari teori MM tanpa pajak yaitu Nilai perusahaan tidak bergantung pada struktur modalnya. Dengan kata lain, manajer keuangan tidak dapat meningkatkan nilai perusahaan dengan merubah proporsi debt dan equity yang digunakan untuk membiayai perusahaan.

Hasil analisis data dalam penelitian ini sejalan dengan penelitian yang dilakukan oleh Ardison (2012) yang meyatakan bahwa Struktur modal atau leverage tidak dapat memoderasiprofitabilitas terhadap harga saham.

\section{PENUTUP}

\subsection{Kesimpulan}

Berdasarkan data penelitian dan hasil pengujian analisis statistik yang telah dilakukan, maka dapat ditarik beberapa kesimpulan bahwa :

1) Profitabilitas tidak berpengaruh terhadap harga saham. Dalam hal ini peneliti beranggapan Investor tidak hanya melihat profitabilitas perusahaan dalam jangka pendek tetapi juga profitabilitas perusahaan dalam jangka panjang, misalnya dengan melihat nilai EVA (Economic Value Added), dimana investor dapat mengestimasi keuntungan ekonomis perusahaan selama periode tertentu dan secara substansial berbeda dengan laba akuntansi, hal ini disebabkan oleh adanya elemen biaya modal yang diperhitungkan dalam EVA yang tidak diperhitungkan dalam laba akuntansi tradisional.

2) Kebijakan dividen mampu memoderasi pengaruh profitabilitas terhadap harga saham, Interaksi antara Kebijakan dividen dengan Profitabilitas berpengaruh positif dan signifikan terhadap harga saham. Perusahaan dengan Profitabilitas yang tinggi tidak dapat dipastikan akan memiliki harga saham yang tinggi juga, hal tersebut akan menjadi berbeda jika perusahaan dalam kondisi mengeluarkan kebijakan dividen. Kebijakan dividen merupakan sebuah sinyal baikbagi investor dalam mengambil keputusan investasi, jika dividen yang dibagikan perusahaan semakin besar, hargasaham perusahaan tersebut akan semakin tinggi, sehingga kebijakan dividen akan memperkuat pengaruh profitabilitas terhadap harga saham.

3) Leverage tidak dapat memoderasi pengaruh profitabilitas terhadap harga saham.Struktur modal yang optimal berada pada keseimbangan antara manfaat pajak atas penggunaan hutang dengan biaya yang berhubungan dengan kebangkrutan, pada tingkat hutang yang optimal diharapkan nilai perusahaan akan mencapai nilai optimal, 
dan sebaliknya apabila terjadi tingkat perubahan hutang sampai melewati tingkat optimal atau biaya kebangkrutan, hutang akan mempunyai efek negatif terhadap harga saham perusahaan.

\subsection{Saran}

Berdasarkan hasil penelitian dan kesimpulan yang telah diberikan, diajukan beberapa saran, antara lain sebagai berikut :

1) Perusahaan disarankan untuk memberikan perhatian terkait penilaian investor terhadap kinerja perusahaan, perusahaan bisa memakai CSR(Corporate Social Responsibility) Sebagai sebuah signal kepada seluruh stakeholder termasuk calon investor mengenai prospek perusahaan di masa depan serta menunjukkan nilai lebih yang dimiliki oleh perusahaan.

2) Bagi penelitian berikutnya, perlu memperhitungkan Profitabilitas perusahaan dalam jangka panjang. Misalnya dengan menggunakan EVA (Economic Value Added) sebagai variabel Independen

\subsection{Keterbatasan dan Arah Penelitian Ke Depan}

Berdasarkan penelitian yang telah dilakukan terdapat beberapa keterbatasan dalam penelitian, sehingga diberikan saran untuk arah penelitian kedepan, yaitu :

1) Profitabilitas yang digunakan hanya mengukur kinerja perusahaan dalam jangka pendek, untuk penelitian selanjutnya bisa menggunakan variabel lain seperti EVA (Economic Value added) untuk mengukur kinerja perusahaan dalam jangka panjang.

2) Leverage yang digunakan belum mampu menentukan tingkat hutang yang optimal yang mampu menaikkan dan memaksimalkan harga saham perusahaan, untuk penelitian selanjutnya bisa melihat trend harga saham serta nilai kombinasi dari utang dan ekuitas perusahaan secara time-series. Dengan begitu akan bisa terlihat seberapa besar nilai kombinasi yang optimal antara utang dan ekuitas pada saat nilai harga saham perusahaan tinggi.

\section{DAFTAR KEPUSTAKAAN}

Ananda N.A, Hermanto, I Nyoman Nugraha Ap (2016). Pengaruh Profitabilitas, Growth Opportunity Terhadap Nilai Perusahaan dengan Struktur Modal Sebagai Variabel Intervening Pada Perusahaan Property, Real estate \& Building Construction Di BEI Periode 2011-2014, Jurnal Magister Manajemen, Universitas Mataram.

Anggraini (2017) Pengaruh profitabilitas Terhadap Nilai Perusahaan Dengan Struktur Modal Sebagai Variabel Moderasi, Studi Kasus Pada Perusahaan Yang Terdaftar Di Jakarta Islamic Index Periode 2012-2016. Skripsi Fakultas Ekonomi Universitas Islam Negeri Maulana Malik Ibrahim, Malang.

Ardison, R.,Nelmilda.,Rika D (2012). Pengaruh Pertumbuhan Perusahaan Dan Profitabilitas Terhadap Harga Saham Dengan Struktur Modal Sebagai Pemoderasi (Perusahaan Manufaktur yang Listed di BEI), Jurusan Manajemen, Fakultas Ekonomi, Univesitas Bung Hatta.

Ayu, R,P.,Emrinaldi (2017). Pengaruh Kinerja Keuangan Terhadap Nilai Perusahaan Dengan Kebijakan Dividen Sebagai Faktor Pemoderasi Bank Pembangunan Daerah Tahun 2001-2011, Jurnal Program Pascasarjana Fakultas Ekonomi Universitas Riau.

Brigham, E F. dan Houston, J F.,(2001), "Manajemen Keuangan II",Salemba Empat, Jakarta. Brigham, E F. dan Houston, J F., (2011), “Dasar-dasar Manajemen Keuangan”, Edisi 11, Salemba Empat, Jakarta. 
Brealey, RA Myers, S.C., dan Marcus A.J, (2006). Dasar-Dasar Manajemen Keuangan Perusahaan, Erlangga, Jakarta.

Djazuli, (2006),"Pengaruh EPS, ROI dan ROE Terhadap Perubahan Harga Saham Pada Perusahaan Sektor Manufacturing Pada Bursa Efek Jakarta (BEJ)".

Husnan, Suad dan Enny Pudjiastuti. (2004). Dasar-Dasar Manajemen Keuangan, Edisi Keempat. Yogyakarta :UPP AMP YKPN.

Jogiyanto, HM. (2008). Analisis $\mathcal{E}$ desain Sistem Informasi, Pendekatan Terstruktur Teori dan Praktek Aplikasi Bisnis.Yogyakarta.ANDI.

Kasmir. (2009). Analisis Laporan Keuangan. Jakarta: Bumi Aksara.

Myers, S.C. (2001). Capital Structure. The Journal Of Economic Perspectives, 15 (2), 81-102

Mahadewi,(2014),"Pengaruh Return on Asset, Earning Per Share, dan Debt Ratio Terhadap Harga Saham Pada Perusahaan Indeks LQ-45 di BEI".

Natasya, Aninda.,Deannes Isyuwardana., Dedik Nur Triyanto, (2017)."Pengaruh Earning Per Share, Return On Assets dan Debt to Equity Ratio Terhadap Harga Saham (Studi Kasus Pada Kelompok Indeks LQ45 Yang Terdaftar di Bursa Efek Indonesia Periode 2012-2015), Jurnal Fakultas Ekonomi dan Bisnis, Universitas Telkom.

Setyawan, R.,(2015).Pengaruh Kinerja Keuangan Terhadap Nilai Perusahaan Dengan Pengungkapan Corporate Social Responsibility Dan Kebijakan Dividen Sebagai Variabel Pemoderasi (Studi Empiris pada Perusahaan Manufaktur di Bursa Efek Indonesia), Jurnal Manajemen Fakultas Ekonomi Bisnis Universitas Muhammadiyah Yogyakarta.

Sutrisno. (2012). Manajemen Keuangan Teori, Konsep, dan Aplikasi Edisi Kedelapan. Yogyakarta: Ekonesia.

Weston dan Copeland. (1996). Financial Theory and Corporate Policy. Wesley Addison. 